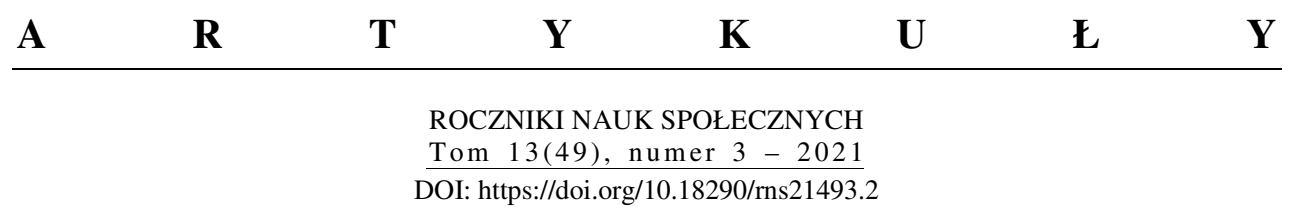

KS. MACIEJ HUŁAS

\title{
HISTORYCZNOŚĆ I NORMATYWNOŚĆ SFERY PUBLICZNEJ HABERMASA
}

\section{WPROWADZENIE}

Koncepcja sfery publicznej Jürgena Habermasa stanowi ważny punkt odniesienia w studiach nad życiem publicznym i autonomią obywatelską. Opisana jako archetyp oddolnego formowania zbiorowej woli obywateli z sygnaturą prawowitej sprawczości politycznej, jest wymieniana jako jedna z klasycznych wykładni życia publicznego. Wtopiona w złożoną rekonstrukcję genezy i rozpadu autonomii obywatelskiej, koncepcja sfery publicznej Habermasa otwarła przed nim podwoje akademickiej samodzielności. Analitycy badający ten szczególny aspekt jego myśli uważają, że jest osią, wokół której obraca się cała jego teoria społeczna (Fraser, 2009, s. 148; Outhwaite, 2009, s. 6; Kellner, 2009; Schröter, 2007, s. 242; Giddens, 2006, s. 118; Holub, 1994, s. 11; Dews, 1993, s. 362; Hohendahl, Russian, 1974, s. 45). Zawłaszczanie czynnika ludzkiego przez wszechobecną „logikę” wydajności (Habermas, 1970, s. 56-74); spór o pozytywizm i historycyzm, koncepcja interesów poznawczych, zwłaszcza interesu emancypacyjnego (Habermas, 1969a, s. 236; [1963] 1968, s. 120-145; [1965] 1968, s. 146-168; [1968] 1973); kryzysy późnego kapitalizmu i poszukiwanie nowych źródeł integrujących tożsamości zbiorowe (tenże, [1973] 2015; 1976); idealna sytuacja komunikacyjna (tenże, [1972] 1984); religia jako niedostrzegany rezerwuar racjonalności publicznej (tenże, [1985] 2000; 1988; 2005; 2012); związek legalizmu i moralności (tenże, [1992] 2005); wreszcie związek nauki i wiary (tenże, 2019) - diagnozy Habermasa i ustalenia w wymienionych

Ks. dr hab. MACIEJ HuŁAS - Katedra Katolickiej Nauki Społecznej i Socjologii Moralności, Instytut Nauk Socjologicznych, Katolicki Uniwersytet Lubelski Jana Pawła II; adres do korespondencji: Al. Racławickie 14, 20-950 Lublin; e-mail: maciej.hulas@kul.pl; ORCID: https://orcid.org/0000-00032833-972X. 
materiach problemowych, istotnie, znajdują dopełnienie w koncepcji sfery publicznej, bądź są jej rozwinięciem.

Przedmiotem niniejszych studiów jest eksploracja warunków historycznego zaistnienia sfery publicznej Habermasa oraz normatywności, której zawdzięcza ona status organizująco-normującej zasady porządku ustrojowego. Normatywność zawsze osadzona jest w historyczności; realizacja wartości artykułowanych w sferze publicznej dokonuje się za pośrednictwem norm, których dostarcza historyczność czerpiąca $\mathrm{z}$ aktualnych orientacji moralnych. Habermas przedstawił koncepcję sfery publicznej w dwóch „odsłonach”: historyczno-krytycznej na początku lat sześćdziesiątych i systematyczno-państwowo-prawnej na początku lat dziewięćdziesiątych. Są to de facto dwie cezury wieńczące dłuższe procesy rozwojowe w genealogii sfery publicznej. Ponieważ „odsłony” dokumentują ewolucję koncepcji sfery publicznej Habermasa, one również wyznaczają strukturę niniejszego studium. Rozpoczyna je: semantyczna analiza pojęcia sfery publicznej; po niej następuje eksploracja jej oryginalnego modelu mieszczańskiego, ze wskazaniem na okoliczności dokonywania korekt; na koniec pozostaje pytanie o funkcję sfery publicznej w demokratycznym państwie prawa.

\section{HISTORYCZNOŚĆ I NORMATYWNOŚĆ ÖFFENTLICHKEIT}

Pisząc o sferze publicznej, Habermas posługuje się terminem Öffentlichkeit (przestrzeń komunikacji społecznej; komunikująca się zbiorowość; jawność jako zasada). O specyfice znaczeniowej Öffentlichkeit stanowią jej derywaty: öffentlich i offen oraz publicus, Publikum, Publizität.

Pierwszy raz pojęcia Öffentlichkeit użyto w 1765 r. w odniesieniu do środka powszechnej komunikacji, która gdy pozostawiona bez cenzury, miałaby szerzyć błędne, złośliwe i niebezpieczne opinie. Przed rewolucją francuską Öffentlichkeit oznaczało samoświadomość społeczeństwa obywatelskiego oraz rzeczy jawne, niezwiązane z rutyną życia. Po rewolucji odnosiło się do rzeczy, czynności, zdarzeń powszechnie dostępnych; wolności obywatelskich, idei partycypacji politycznej społeczeństwa (Hułas, 2019, s. 159 n.; Koselleck, 1972, s. xxii; Hölscher, 1979, s. 118 n.). Öffentlichkeit zyskuje na znaczeniu wraz z upowszechnieniem druku; kształtuje krytyczną opinię obywateli, która dzięki jawności spraw publicznych i wolności prasy aspiruje do rangi siły politycznej.

Öffentlich (jawny, ogólny) i offen (otwarty, wolny, odkryty, szczery) pozostają w znaczeniowej bliskości z offenbar (oczywisty). W średniowieczu i wczesnej nowożytności öffentlich oznaczało: jawność, szczerość i jasność 
przekazu, otwartość wobec świata; działanie jawne dokonywane w obecności wszystkich, poza obszarem prywatnym gospodarstwa domowego: akty zwierzchnictwa, wymiana rynkowa, egzekucje skazańców. Kategoria „wszyscy" odnosiła się do dzielących konkretny świat wewnętrzny, odseparowany od świata zewnętrznego: miasto, system prawny, ulicę. Powietrze, światło czy zapach nie stanowiły materii öffentlich, gdyż nie wyodrębniały świata wewnętrznego. Przeciwieństwem jawności jest utajnienie jako ograniczenie uzasadnionego dostępu wskutek zamierzonego działania (Hułas, 2019, s. 156; Hölscher, 1979, s. 11-23; Hohendahl, 2000, s. 5).

Publicus (publiczny) związane jest z ogółem. Określenia res publicae, res communis odnosiły się do dóbr w dyspozycji całego populus Romanus. W średniowiecznej Europie (północnej) publicus oznaczał: dobra, do których wszyscy mieli prawo, oraz takie, które służąc każdemu z osobna, pozostawały wspólne; dobra nadane wspólnocie do użytkowania przez władzę najwyższą; oraz atrybut suwerena. W nowożytności terminy publicus i privatus odnosiły się do dwóch porządków: politycznego i ekonomicznego (Hułas, 2019, s. 156 n.; Hölscher, 1979, s. 35-57, 62, 74 n.).

Publikum (publiczność) oznacza konsumentów dzieł kultury; czytelników, audytorium skupione w konkretnym miejscu; wykształcone mieszczaństwo; wspólnotę zainteresowań, poglądów, sądów i tradycji. Publikum pozostaje w genetycznym związku z językiem (Hułas, 2019, s. 158 n.; Warner, 2002, s. 49 n.). Upowszechnienie literatury w językach narodowych prowadziło do identyfikacji rozproszonych czytelników z tekstami standaryzującymi język; konsolidowało i wspierało tożsamość zbiorową; jednoczyło konsumentów kultury sprawiając, że rozproszone stanowiska stapiały się w zbiorowym podmiocie odbiorcy i jego opinii (Hölscher, 1979, s. 83-90).

Historyczne urzeczywistnienie Öffentlichkeit integrującej wartości öffentlich, offen, offenbar, publicus, Publikum dokonuje się na styku dwóch domen: publicznej domeny państwa i prywatnej domeny życia zwykłych ludzi, obejmującej działania podporządkowane potrzebom egzystencji oraz podpadające pod kategorię kultury (Hohendahl, 2000). Historyczną materializację Öffentlichkeit można zobrazować jako proces, który, zainicjowany w antyku, poprzez różne momenty zwrotne, osiąga swój ,złoty wiek” w etosie mieszczańskim (przedkonstytucyjnym i wczesnoparlamentarnym).

Normatywność Öffentlichkeit związana jest z Publizität (jawność, rozgłos, przyciąganie uwagi). Najwyraźniej daje o sobie znać w zestawieniu jawności z jej kontrapunktem - utajeniem. Otwartość Öffentlichkeit umożliwia partycypację wszystkich $\mathrm{w}$ zdarzeniach publicznych oraz indywidualne wypowiadania opinii 
tworzących opinię publiczną. Jawność, szczerość i jasność przekazu w Öffentlichkeit wyznacza kodeks moralny z manichejską metaforyką: jasny vs niejasny; widoczny vs niewidoczny, dostępny vs niedostępny. Odnosi się on do rozstrzygnięć istotnych dla życia codziennego; utajnienie, skrytość, niejasność, niedostępność są kojarzone z działaniem obawiającym się poddania pod skrutynium społeczeństwa. Öffentlichkeit nadaje moralnego charakteru kategoriom politycznym; jest synonimem dobrego sumienia i zaufania między władzą a społeczeństwem. W połączeniu z Publikum, Öffentlichkeit wyobraża organizm społeczny, wspólnotę losu i ducha. Motyw związku osób tworzy metaforykę organizmu Öffentlichkeit, będącego podstawą jej funkcji społecznych i politycznych. Wszystkie formy komunikacji w obrębie sfery publicznej miały być organicznie powiązane, gwarantując wolność wszystkim uczestnikom zdolnym wytwarzać opinię publiczną, odpowiadającą jawności urządzeń państwa. Metaforyka organizmu przeciwstawia Öffentlichkeit, jako „żywą” wspólnotę demokratyczną, „martwemu" reżimowi absolutystycznemu; ukazuje ją jako zdrową, korzystną i pobudzającą witalnie sferę działań. Öffentlichkeit postrzegano jako układ nerwowy organizmu społecznego, konwerter zmieniający rozproszoną masę w organiczną jedność, i uważano za warunek zdrowego społeczeństwa oraz duchowego oddziaływania natury społecznej (Hölscher, 1979, s. 120-131, 138-140; Peters, 1993, s. 55 n., 60; Eisenstadt, 2000, s. 8; Hułas, 2019, s. 161 n.).

\section{MIESZCZAŃSKA SFERA PUBLICZNA}

Sfera publiczna, której Habermas nadaje formę koncepcji, jest opisana m.in. jako „unikalna jednostka ontyczna” (Eisenstadt, 2006, s. 2) i ,imaginarium społeczne" nowoczesności (moderny) (Taylor, 2007, s. 159-211). Jej materialna postać stanowi przedmiot odrębnych analiz (Kleinstüeber, 2001). Dla celów niniejszego studium istotne jest nowożytne pochodzenie sfery publicznej. Nie sposób jej zrozumieć w oderwaniu od nowoczesności (moderny), z którą jest genetycznie związana.

\subsection{NORMATYWNOŚĆ NOWOCZESNOŚCI}

Nowoczesność kontynuuje procesy późnego średniowiecza: postęp naukowy, wzrost i zagęszczenie ludności w miastach, technicyzacja oraz różnicowanie stylów życia, wzrost potrzeb, wyobcowanie wskutek biedy - czyni to jednak 
w sposób antytetyczny; jest bowiem epoką dziejowej dezintegracji i różnicowania. Przyjmując matrycę Habermasa, jedno i drugie opiszemy w aspekcie (1) historycznego rozbratu racjonalności z tradycją oraz (2) jego krytyczno-normatywnych konsekwencji.

Ad (1). Nowoczesność pojawia się jako zaskakująca mutacja kulturowa w Europie (Krasnodębski, 2005, s. 20). Jest ideowym programem nowożytności (Eisenstadt, 2000). Zmienia wyobrażenie o człowieku, świecie i rządzących nimi siłach. Nowoczesny humanizm - jako reakcja na wcześniejsze poddanie wszystkiego normom porządku wyższego - dystansuje się od religii; na nowo kreuje i kształtuje zarówno świat natury, jak i społeczny świat ludzki mocą przeświadczenia o naturalnym dobru istoty ludzkiej. Duchowość religijna nowoczesności akcentuje indywidualną kontemplację (Mistrz Eckhart, Tomasz à Kempis, Ignacy Loyola). Siedemnastowieczny mechanicyzm nauki uderza w magię i wierzenia. Nowoczesna świadomość - jako jedyne umiejscowienie myśli, uczuć i duchowości - zamyka się na siły kosmiczne, ufa we własną moc orientacji moralnych i tworzy autonomiczny porządek dla samej siebie. Kosmos - wyobrażenie uporządkowanej całości wyznaczającej porządek życia - w nowoczesności ustępuje wyobrażeniu uniwersum - przedmiotowi eksploracji i ustaleń (Taylor, 2007, s. 27, 63).

Oderwanie racjonalności od tradycyjnych światopoglądów religijnych i metafizycznych zapoczątkowało proces autonomizacji trzech istotnych aspektów kultury: wiedzy, etyki i estetyki (Habermas, 2003, s. 15-17, 22-26). Zaczęły one funkcjonować we własnych zinstytucjonalizowanych sferach wartości. Wiedza i poznanie poddane metodologicznemu rygoryzmowi scjentyzmu zamknęły się w specjalistycznym systemie nauki (Habermas, [1968] 1973; [1963] 1968). Etyka, której miary dobra i słuszności pochodziły z ustaleń powstałych na bazie eksploracji porządku natury - jedynego ukonkretnienia niezmiennego zamysłu Stwórcy, zamknęła się w systemie moralności. Na jej straży stała akademia, zdolna kompetentnie wnikać w świat natury, a przez to dawać zrozumienie zachodzących w nim związków i procesów (Locke, [1689-1690] 1824, § 7-10). Estetyka została wciśnięta w ,żelazny gorset” sztuki, w której gustów nie wyznaczały klasyczno-normatywne wzorce piękna, lecz decydował o nich indywidualny osąd, reakcja podmiotu zajmującego stanowisko, powstający w polu napięć indywidualnego odczucia i rozumu (Busch, [1995] 2001).

Ad (2). Racjonalność uwolniona $\mathrm{z}$ tradycji pozwala rozumieć nowość nowoczesności. Podobna jest ona do nowości wcześniejszych epok. Krytycznie ocenia przeszłość; nakręca ją przyspieszenie zdarzeń aktualnych; aktywizuje 
misja wytyczania zadań rozwojowych dla przyszłości i wypracowywanie innowacyjnych rozwiązań dla ich realizacji. Nowość nowoczesności jest jednak bezprecedensowa. We właściwy sobie sposób rozumie czas i wytwarza nieznaną wcześniej samoświadomość. Jest sekularna, tzn. jest przedsięwzięciem aktualnym, w którym gratyfikacji nie odkłada się na później, lecz kapitalizuje w teraźniejszości; wyposażona w racjonalność uwolnioną z tradycji, nowość nowoczesności czuje się kompetentna do wytwarzania własnej normatywności według nowoczesnych doświadczeń i orientacji.

Normatywność nowoczesności powstaje w napięciu dwóch przeciwstawnych modusów myślenia: historycznego i utopijno-eschatologicznego. Są one obecne w ówczesnym dyskursie teoriopoznawczym (Locke, Hume, Reid, Wolff, Kant). Myślenie i doświadczenia historyczne dotyczą indywidualnego przypadku; dają zrozumienie aktualnego osadzenia ich w konkretnych czasoprzestrzeniach; korygują wyobrażenia i zapędy utopijne. Myślenie utopijno-eschatologiczne jest uniwersalistyczne; ukierunkowuje na nieograniczoność; ukazuje horyzonty nowych możliwości, wykraczających poza kontynuacje historyczne. Obydwa modusy są obecne w myśleniu i działaniu mieszczan, twórców i pierwszych uczestników sfery publicznej Habermasa. Nowość nowoczesności integruje je i wyprowadza $\mathrm{z}$ nich normatywność uważaną za prawowitą. Prawowitość nowoczesna znajduje wsparcie w nowym porządku moralnym, który zrywa z dogmatyzmem wcześniejszych orientacji aksjologicznych, asymilując $w$ ich miejsce kulturę oddolności, indywidualizmu i samostanowienia. Paradygmatem nowej moralności było urządzenie i regulowanie świata zwyczajnych działań instrumentalnych. W rutynowych działaniach codzienności, $\mathrm{z}$ ich kluczową zasadą przewidywalności i dotrzymywania umów, wytwarzały się horyzontalne relacje z innymi i dokonywało zharmonizowanie indywidualnych dążeń osiągania szczęścia (Mandeville, [1705] 1957; Smith, [1759] 1853, s. 3-13; [1775-1776] 2007, s. 40; Calhoun, 2007, s. 81).

W ideowym programie nowoczesności uwalnia się świadomość indywidualnego samostanowienia jednostek, które w postrzeganiu samych siebie czują się zrównane jednym uniwersalnym statusem istoty ludzkiej. W klimacie postulatów teoretycznych, orientacji moralnych oraz ich praktycznych implikacji uformował się ideał jednostki autonomicznej, aranżującej i przeżywającej życie według własnych aspiracji i wyobrażeń.

W nowoczesności dezintegracja i różnicowanie stanowią normalne procesy, wpisane w progres. Jej nowa wspólnotowość (naród, klasa, społeczeństwa) i nowa uniwersalność (prawa człowieka) nie są oczywiste, wymagają teoretycznego zrozumienia (Tönnies, 1926, s. 5-26; Schumpeter, [1942] 2009, s. 149-175; 
Jacoby, 1971, s. 181-183). Moderna rozpoczyna zatem epokę niekończących się uzasadnień, rewizji i sprzeczności (Eisenstadt, 2000, s. 7 n.). Jest projektem własnej temporalności, którą naukowo wyjaśnia, normatywnie legitymizuje i estetycznie wyraża.

\subsection{HISTORYCZNOŚĆ MIESZCZAŃSKIEJ SFERY PUBLICZNEJ}

Sfera publiczna Habermasa powstała oddolnie, uwolniona w spontanicznym samozachowawczym odruchu warstw mieszczańskich, sprowokowanym przez nieuprawnione wtargnięcie absolutystycznego państwa w prywatną sferę wolności podstawowych. Zaistniała wraz z politycznym uaktywnieniem potencjałów autonomizujących mieszczaństwa osiemnastowiecznej Anglii, Francji oraz Niemiec. Trzy wymienione konteksty społeczno-narodowe, mimo różnic, egzemplifikują wzorce historycznego urzeczywistnienia postulatów emancypacyjnych zachodniej nowoczesności. Przypadek angielski najbardziej sugestywnie oddaje okoliczności przekonwertowania intelektualnych dyspozycji autonomizujących na potencjał politycznej sprawczości, wyraziście ilustruje zatem dynamikę towarzyszącą zaistnieniu sfery publicznej oraz tłumaczy jej założenia i cele (Edgar, 2005, s. 37; Nathans, 1990, s. 628 n., 632 n., 642 n.).

Sfera publiczna wykluwa się w procesie. Jego pierwszym etapem jest apolityczne nabywanie przez jednostkę emancypujących władz intelektualnych na drodze refleksyjnej internalizacji uniwersalnych wartości kultury wyższej. Habermas opisał go jako „literacką sferę publiczną”. Uformowany w niej intelekt jest bazą rozsądku naturalnej istoty ludzkiej, z którego pochodzi indywidualna racjonalna opinia, nie obawiająca się ujawnienia. Indywidualne dyspozycje intelektu wzmacnia dodatkowo integracja sfery psychoafektywnej związana z mieszczańską funkcją męża i ojca oraz eksploracja indywidualnej podmiotowości, osiągana $\mathrm{w}$ nowych gatunkach literackich: epistolografii i beletrystyce (Habermas, [1962] 2007, s. 126-134; Randall, 2008, s. 221 n.). Rozumienie jako kondycja zintegrowanej osobowości pozwala oceniać warunki aktualne i dostrzegać asortyment dostępnych, moralnie uprawnionych środków działania. „Literacka sfera publiczna” jest politycznie neutralna; formułowane w niej sądy nie odnoszą się do materii newralgicznych. Habermas ukazuje ją jako przedpole nabywania potencjałów intelektualnych i „bezpiecznego" testowania ich skuteczności w postaci opinii o kulturze (Habermas, [1957/1964] 1976; [1962] 2007; Häberle, 1969, s. 276; Saccamano, 1991, s. 688 n.). 
Samostanowienie staje się problemem, gdy zaczyna dysonować z reżimem absolutystycznym, tj. gdy potencjały krytycznej racjonalności, przetestowane w debatach o kulturze, zostają wykorzystane w debatach nad prawomocnością decyzji państwowych; gdy wychodząc $\mathrm{z}$ angielskich kawiarni, francuskich salonów i niemieckich towarzystw naukowych, przekroczą Rubikon polityki i realnej władzy. Ten właśnie dysonans Habermas wymienia jako bezpośrednią przyczynę zaistnienia sfery publicznej.

Sfera publiczna Habermasa pojawia się jako reakcja szeregowych obywateli na nieuprawnione zawłaszczanie wolności podstawowych przez państwo: wolności swobodnego rozporządzania własnością prywatną oraz wolności swobodnego formułowania opinii. Zaczyna istnieć, gdy intelektualny potencjał emancypacyjny materializuje się jako front mieszczan rzucających wyzwanie autorytarnemu państwu. Bezpośrednim kontekstem zaistnienia sfery publicznej jest wczesnoliberalny wolny rynek obrotu towarowego i pracy najemnej oraz obrotu informacją. Arbitralność ingerencji państwowych w procesy wolnego rynku sprawia, że państwo działa wbrew zasadom nowego (nowoczesnego) porządku społecznego: wprowadza nieznany wcześniej czynnik sankcji i politycznej dominacji w świat spontanicznych, prywatnoprawnych relacji ekonomicznych; nieobciążona ryzykiem arbitralność państwa (uczestnika uprzywilejowanego) dysonuje z oddolnością indywidualnych strategii rynkowych, obciążonych ryzykiem zagrożonej reprodukcji materialnej; obecność polityki i sankcji państwowej w systemie wczesnoliberalnej ekonomii destabilizuje porządek społeczny, w którym przednowoczesna wieczna cnota jako miara eschatologicznych spełnień ustępuje miejsca indywidualnemu dążeniu jednostek do szczęścia. Reglamentując swobodę działań ekonomicznych, państwo narusza najistotniejszą domenę prywatności, którą w świecie wczesnoliberalnym stanowi ekonomia i rynek - jest to podręcznikowy przykład naruszenia wolności podstawowych. Mieszczańskie niezadowolenie, spowodowane tego typu ,aktywną” obecnością, wzmaga dodatkowo państwowa inwigilacja niezależnej żurnalistyki moralno-światopoglądowej, której lektura sprzyja formułowaniu stanowisk krytycznych i swobodnej cyrkulacji poglądów. Niereglamentowany dostęp do tego typu tekstów budzi obawy państwa; niezależna redakcja zostaje postrzegana jako ważny ośrodek autonomizacji społeczeństwa (Habermas, [1962] 2007, s. 85-94; [1957/1964] 1976, s. 224).

Osadzenie przez Habermasa genezy sfery publicznej w kontekście rynkowego naruszania wolności podstawowych wykazywano jako mankament jej warstwy historycznej. W opinii niektórych krytyków wyeksplikowana pierwszoplanowość naruszanych wolności rynkowych przysłania inne obszary życia, 
z których wychodziły impulsy autonomicznego myślenia: oddolne nonkonformistyczne ruchy w protestantyzmie; standaryzacja nauki i taksonomii umożliwiająca dialog, w którym argument dominuje nad autorytetem (Zaret, [1992] 1996, s. 213-229; Loewenstein, Stevens, 2004; Hansen, [1972] 1993, s. xxvii-n) oraz inne. Jak zatem traktować historyczność sfery publicznej Habermasa? W jakim stopniu jej rekonstrukcja odpowiada rzeczywistym stanom rzeczy?

Otóż tworząc swą koncepcję na przełomie lat 50. i 60., Habermas pozostawał pod wpływem szkoły frankfurckiej. Wzorem Horkheimera i Adorno szukał potwierdzenia dla historycznego urzeczywistnienia autonomii i emancypacji w konkretnej praktyce życia (Hohendahl, [1992] 1996, s. 101). Warstwa historyczna, jakkolwiek przystająca do stanów faktycznych, nie obciąża merytorycznego waloru koncepcji sfery publicznej; służy wyłącznie wyjaśnieniu powodów i okoliczności jej zaistnienia oraz określa jej przeznaczenie (Kleinstüber 2001, s. 100). Wyeksponowana pierwszoplanowość rynku wydaje się najbardziej sugestywnie oddawać psychologiczno-społeczny klimat, w którym - według Habermasa - doszło do konfrontacji obywateli z państwem (Kramer, [1992] 1996, s. 244 n.). Sfera publiczna powstaje jako skutek połączenia trzech elementów: rozbudzonej świadomości politycznej (nowoczesność), rezonującego społeczeństwa (kultura) i inwigilacji państwowej (Schneider, 1966, s. 12).

\subsection{NORMATYWNOŚĆ MIESZCZAŃSKIEJ SFERY PUBLICZNEJ}

Jakim wartościom sfera publiczna Habermasa zawdzięcza swój status organizująco-normującej zasady porządku ustrojowego? Otóż mobilizuje dążenia zwykłych ludzi usiłujących bronić wolności podstawowych, zawłaszczanych przez państwo absolutystyczne. Prawowitości roszczeniom formułowanym w sferze publicznej nadaje uniwersalna moralność, chroniąca wartości ogólnoludzkie, tu - samostanowienie. Powyższe stwierdzenie oddaje istotę tego, co stanowi o normatywności sfery publicznej Habermasa. Przełożenie jednak idei na praktykę dokonuje się w konkretnych procedurach, według konkretnych reguł. Normatywność sfery publicznej Habermasa przenika do praktyki trzema kanałami i odnosi się do trzech istotnych materii problemowych: dostępności (otwartości) sfery publicznej, reguł uczestnictwa (debaty), edukacji obywatelskiej.

Dostępność jest zasadniczą cechą każdej sfery publicznej. Czy zatem sfera publiczna Habermasa jest otwarta dla wszystkich? Jest otwarta dla każdego, 
kto jest w stanie skutecznie rzucać wyzwanie zawłaszczającemu panowaniu, tj. dla każdego, kto ma ku temu tytuł i środki. W wolnorynkowym kontekście zawłaszczenia praw podstawowych wyzwanie panowaniu rzucają poszkodowani: właściciele kapitałów (Besitz) i czytelnicy żurnalistyki moralnej (Bildung); warstwy o ugruntowanej pozycji ekonomicznej i wyrobionym intelekcie: handlowcy, producenci, finansjera, wydawcy, właściciele manufaktur; oraz warstwy bytowo zależne od państwa: urzędnicy, uczeni sponsorowani przez dwór, zależni od patronatu arystokracji (Calhoun, 2007, s. 82 n.). Mieszczaństwo, operując kapitałem w zasięgu kontynentalnym, zyskuje autorytet sprawdzonej rękojmi umów, decyduje o rozwoju gospodarczym; zabezpiecza ciągłość operacji gospodarczo-finansowych i jest wierzycielem państw (Koselleck, [1959] 2015, s. 147 n.). Jest zatem ważnym podmiotem, który - w samoświadomości pełnionych funkcji - wymusza na władzy poddanie jej legislacji ekonomicznej pod skrutynium opinii publicznej. Tak zdecydowane roszczenia mieszczaństwa są formułowane na gruncie zagrożonej własności (egzystencji) i wspiera je racjonalno-krytyczna świadomość wykształcenia. Posiadanie zatem własności i wykształcenia decyduje o statusie pełnoprawnego obywatelstwa, które swe postulaty wypowiada w mieszczańskiej sferze publicznej i dla którego medium to jest otwarte.

Obwarowanie uczestnictwa elitarnością własności i wykształcenia ogranicza - jak się wydaje - możliwość uczestnictwa w życiu publicznym dla wąskich warstw burżuazji czy jednak narusza zasadę wolnego dostępu? Według Habermasa istnienie sfery publicznej ma sens, gdy jest ona w stanie zmieniać zastaną rzeczywistość. W warunkach przedkonstytucyjnych sprawczość polityczna była związana z podmiotowością naturalnej istoty ludzkiej, umocowanej w wolnościach podstawowych (status negativus). Chroniła jej uniwersalna moralność, uzasadniana teoretycznymi postulatami nowoczesności. Jeżeli Habermas przyjmuje racjonalność burżuazyjną za wzorcową, tzn. jeżeli uważa, że jej sens normatywny ma być odtwarzany w każdej temporalności późniejszej, to siłą rzeczy przyjmuje również okoliczności i środki, które ją urzeczywistniają. W racjonalności burżuazyjnej są nimi własność, wykształcenie oraz wolny rynek, gdyż - przy nieistnieniu podmiotowości obywatelskiej gwarantowanej konstytucyjnie - ich posiadanie stanowi tytuł i daje środki podmiotowego uczestnictwa w kluczowych obszarach życia: ekonomii i kulturze. Problem otwartości mieszczańskiej sfery publicznej, wykluczającej kobiety i warstwy niedysponujące kapitałem, sygnalizowany był zwłaszcza po 1989 r., gdy po publikacji angielskiego przekładu Strukturalnych przeobrażeń koncepcja Habermasa zaczęła bardziej przenikać do akademii anglojęzycznej. 
Stanowiska krytyczne z reguły pochodzą z innych kontekstów i innych doświadczeń niż kontekst i doświadczenia Habermasa. Wyczuwalne jest w nich rozczarowanie spowodowane niemożnością znalezienia w jego koncepcji sfery publicznej orzeczeń potwierdzających zasadność oczekiwań, które z gruntu zakładają krytykę etosu mieszczańskiego (Landes, 1988, s. 40, 127, 147 n.; Allen, 2012, s. 822; Fleming, 1993, s. 29, 33, 38, 42 n.; Baker, [1992] 1996, s. 198 n.; Fraser, [1992] 1996, s. 118 n.; Hułas, 2019, s. 243-268).

Ad 2. Reguty uczestnictwa. Debata obywatelska Habermasa z założenia jest wolna od jakichkolwiek czynników dominacji. Obowiązuje w niej autorytet merytorycznego argumentu, który weryfikowany w osądzie zdrowego rozsądku, uzyskuje właściwości uniwersalistyczne. Te z kolei, wprowadzone do debaty obywatelskiej, wzmacniają jej komponent egalitaryzujący. Instancją przyznającą słuszność formułowanym argumentom jest zatem uniwersalna kategoria zdrowego rozsądku. Uczestnictwo w debacie publicznej bazuje na konkretnych dyspozycjach osobowych: aktywności, kompetentnym zorientowaniu w materii aktualnych problemów oraz świadomym angażowaniu się na rzecz ich rozwiązywania (Habermas, [1961] 1969b, s. 16).

Model debaty obywatelskiej Habermasa ewoluuje odpowiednio do ewolucji sfery publicznej. W warunkach mieszczańskich debata przyjmuje postać rezonującego rozprawiania (Räsonnement) (Habermas, [1962] 2007, s. 95). Chodzi o refleksyjne formułowanie stanowiska wyrażającego sąd o danej materii problemowej w debacie umożliwiającej swobodną cyrkulację opinii. Rozprawianie jest procesem monologicznym. Mocą rozwiniętych dyspozycji intelektualno-osobowych i samoświadoma ryzyka, jakim arbitralność państwa obciąża bazę jej materialnej egzystencji, jednostka mieszczańska poprzez wymianę opinii formułuje własny sąd co do prawdziwości i moralnej obowiązywalności wysuwanych oddolnie roszczeń. Racjonalność mieszczańska jest scentralizowana w prawdziwości sądu.

W drugiej systemowo-państwowoprawnej odsłonie sfery publicznej, po zwrocie lingwistycznym w latach 70., debata publiczna przybiera postać deliberacji. Mimo że rozprawianie i deliberacja uaktywniają te same osobowe władze samostanowienia i rozsąaku publicznego, nie są tożsame. Różnica jest skutkiem przeniesienia oryginalnego sensu normatywnego debaty publicznej z poziomu mieszczańskiego na poziom rzeczywistości systemowej.

Habermas zgadza się z Luhmannem, że autokataliza ewolucji społecznej spowodowana trudnością komunikacyjną w warunkach „,podwójnej kontyngencji” (Brunkhorst, 2009, s. 367; Głażewski, 2016, s. 14) koncentruje się w złożoności systemu społecznego; że systemowość z jej wyspecjalizowanym 
układem kontroli, sterowalności, regulacji i ekspertyzy jest bezdyskusyjnym, bezalternatywnym stanem faktycznym zaistniałym w ewolucji społecznej; że wysoki poziom specjalizacji systemowej w społeczeństwach późnego kapitalizmu nie sprzyja formowaniu tożsamości zbiorowych czerpiących z tożsamości indywidualnych i z aksjologii tradycyjnych (Luhmann, 1970). Stanowczo odrzuca jednak tę część tezy Luhmanna, w której ten dowodzi funkcjonalnej zbędności czynnika ludzkiego w rzeczywistości systemowej. Dla Habermasa czynnik ludzki jest absolutnym priorytetem, dlatego szuka dla niego nowych przestrzeni aktywnej obecności.

Według Habermasa usiłowanie jednoczenia się aktorów społecznych w warunkach systemowych jest konstytutywne dla nowej postaci autonomii komunikacyjnej, która uodparnia jednostkę i jej świat życia na działanie kolonizującej mocy systemów. Tym, co ma ich skłaniać do komunikacji, jest konieczność namysłu nad zasadnością wysuwanych roszczeń co do prawdziwości i obowiązywania. W przypadkowości i nieprzewidywalności świata systemowego nie znikają pytania o to, co ma uchodzić za słuszne i obowiązujące. Są one wpisane w ewolucję gatunku ludzkiego. Habermas uważa, że w warunkach osłabionych aksjologii tradycyjnych, niezdolnych społecznie integrować zbiorowości niejednorodne ideowo, jedyną instancją władną określać słuszność i obowiązywalność jest dyskurs. Uwaga uczestników koncentruje się w nim na uzasadnianiu powodów, dla których proponowane rozwiązanie miałoby uchodzić za najbardziej optymalne.

W debacie obywatelskiej Habermasa obowiązuje: (1) wolność swobodnego posługiwania się aktami mowy; (2) równość interpretacyjnego przedstawiania własnego stanowiska poprzez twierdzenia, propozycje, problematyzowanie, uzasadnianie i obalanie aktualnych roszczeń obowiązywania; (3) swoboda manifestowania autentycznych odczuć, nastawień i oczekiwań; (4) równość wydawania poleceń oraz sprzeciwiania się im, zezwalania i zabraniania, zdawania sprawy i żądanie tego samego od innych. Wyszczególnione cztery warunki uczestnictwa zabezpieczają cztery ważne komponenty debaty: wolność, oryginalność, autentyczność i autonomiczność (Habermas, [1972] 1984, s. 177 n.). One też tworzą idealną sytuację komunikacyjną, w której zwieńczeniem debaty jest konsens. Zarówno w rozprawianiu, jak i w deliberacji panują warunki otwartości i szczerości.

O ile przedmiotem mieszczańskiego rozprawiania jest dowolna materia problemowa (kultura i polityka), o tyle deliberacja odnosi się do materii stricte politycznej. Urzeczywistniana w aktach komunikacji językowej deliberacja zabezpiecza autonomię uczestniczących w niej aktorów społecznych 
oraz rozsądek publiczny; zakłada dialogiczność i dopuszcza dowolną grupę uczestników (Llanque, 2003, s. 172 n.). Jej procedury, zastosowane dla celów wyłaniania zbiorowej woli w demokratycznym państwie prawa, Habermas uznaje za mechanizm prawowitego panowania.

Ad 3. Edukacja obywatelska. Sfera publiczna Habermasa kreuje kontekst debat nad kwestiami o istotnym znaczeniu dla praktyki życia. Oznacza to, że nie ma w niej miejsca dla materii błahych. Powyższe stwierdzenie znajduje odzwierciedlenie w praktycznej zasadzie debaty obywatelskiej, jaką daje się wyprowadzić z jego koncepcji sfery publicznej.

Habermas piętnuje w debacie obywatelskiej tzw. niezobowiązujące poglądy, tj. indywidualne oceny i wizje rozwiązań, oparte na subiektywnym przeświadczeniu o ich teoretycznym niewiążącym znaczeniu. Decyzje polityczne finalnie znajdują przełożenie na regulacje wiążące w praktyce. Polityka, w której są określane priorytety dla życia praktycznego, nie może zależeć od przypadkowości poglądów opatrzonych sygnaturą nieprzetestowanej oryginalności czy fałszywego przeświadczenia o ich teoretycznej „neutralności”. Sfery publicznej, w której ważą się losy konkretnej praktyki życia, nie wolno wykorzystywać do testowania idei nowatorskich; nie ma w niej miejsca dla niezaangażowanego poszukiwania rozwiązań, których słuszność czerpałaby z nieokreślonych bliżej miar prawidłowości. Sfera publiczna jest miejscem znajdowania skutecznych rozwiązań dla problemów, które w ukonkretnionych postaciach zaburzają konkretną praktykę życia. Tego typu wnioskowanie odpowiada logice związku interesów praktycznych rządzących poznaniem, opisanych w pracy Erkenntnis und Interesse. Sfera i debata publiczna Habermasa nie są przeznaczone dla teoretyków testujących ,innowacyjności”, lecz dla „brutalnych” realistów, rozumiejących znaczenie interesów życia i zdolnych zabezpieczać je bez zbędnego wystawiania na ryzyko (Habermas, [1961] 1969b, s. 49).

\section{SFERA PUBLICZNA \\ W DEMOKRATYCZNYM PAŃSTWIE PRAWA}

W latach siedemdziesiątych Habermas odchodzi od uniwersalistycznego charakteru racjonalności mieszczańskiej jako podstawy legitymizującej sferę publiczną (Habermas, [1973] 2015, s. 39-48; McCarthy, 2009). Rzeczywistość społeczną opisywaną wcześniej historycznie przenosi na grunt świata systemowego. Ponieważ w zróżnicowaniu i przypadkowości systemowej 
aksjologie tradycyjne, zakorzenione w moralności uniwersalnej, nie wytwarzają podstawy legitymizującej sferę publiczną, Habermas znajduje ją gdzie indziej, mianowicie - w przeświadczeniu o istnieniu uniwersalnej możliwości komunikowania, które każdemu daje równe szanse przedstawiania własnych racji, w procesie ustawicznego komunikacyjnego kształcenia. Przyjmując nową podstawę uzasadnienia dla sfery publicznej, Habermas czyni zwrot od racjonalności zawierającej się w prawdziwości sądu ku racjonalności zawierającej się w warunkach racjonalnej akceptowalności (Habermas, 2001). Sfera publiczna uzyskuje swe umocowanie normatywne $\mathrm{w}$ transcendencji pochodzącej z immanencji komunikacyjnej (Habermas, 1976, s. 115-117; Kaniowski, 1990, s. 436 n.).

Historyczność. W warunkach późnego kapitalizmu, organizowanego i rządzonego przez systemy, sfera publiczna jest częścią systemu politycznego. Krytyczny wobec toczonej kryzysami systemowymi demokracji masowej, Habermas nie ma wątpliwości, że pozostaje ona rdzennym (politycznym), a zatem - bezalternatywnym środowiskiem sfery publicznej (Höffe, 1993, s. 73; Llanque, 2003, s. 171 n., 178). Rzecz w tym, że późnokapitalistyczna demokracja nie kreuje warunków rzeczywistego uczestnictwa obywateli w sprawach państwa, stając się przez to demokracją fasadową. Ażeby uzyskać uprawomocnienie, państwo - argumentuje Habermas - formalnie zachowuje instytucje demokracji (periodyczne wybory), z obawy jednak przed ryzykiem rzeczywistej kontroli agend państwowych przez obywateli, podstawowe instrumentarium demokratycznego uczestnictwa, tj. sferę publiczną, organizuje w taki sposób, by czyniąc zadość formalnemu minimum demokracji obywatelskiej, de facto nie dawać jednocześnie obywatelom możliwości kontroli rzeczywistej (Habermas, [1973] 2015, s. 54-56). Fasadowość tego typu zaprzecza założeniom sfery publicznej i kłóci się z podstawowym założeniem demokratycznego państwa prawa, pozostawiającego obywatelom wyłączne prawa stanowienia o jego sprawach (Böckenförde, 1976, s. 60). Przywrócenie demokracji jej właściwej kondycji dokonuje się na drodze świadomej, aktywnej partycypacji politycznej obywateli świadomych swej sprawczości, realizowanej w sferze publicznej. O historyczności sfery publicznej Habermasa w drugiej odsłonie stanowią zatem okoliczności powodujące kryzysy legitymizacji i motywacji, jakim poddane zostają demokracje późnego kapitalizmu.

Normatywność. Sfera publiczna jest kluczowym ogniwem zapośredniczenia procesów demokratycznej procedury tworzenia legalizmu. W warunkach mieszczańskich roszczenia formułowane w prywatnie ufundowanej sferze publicznej były głosem uniwersalnej moralności (naturalnych istot ludzkich) skierowanym przeciwko nieakceptowalnej arbitralności władzy. Zapośredniczenie 
społeczeństwa i państwa dokonywało się w pozainstytucjonalnej przestrzeni publicznej-nie-państwowej (wiec, kawiarnia). Mieszczańskie samostanowienie realizowało się przez rzucanie wyzwania reżimowi państwowemu w oczekiwaniu jego ugięcia się pod naporem moralnej siły wolności i praw podstawowych. W demokratycznym państwie prawa roszczenia konstytucyjnie umocowanej sfery publicznej są głosem podmiotów prawnych (obywateli) i zawierają propozycje prawomocnej korekty obowiązującego legalizmu, jedynego medium zsynchronizowania i realizacji procesów procedury demokratycznej. Zapośredniczenie społeczeństwa i państwa dokonuje się tu w strukturze uregulowań instytucjonalnych, a podmioty podlegające prawu są jego autorami. W demokratycznym państwie prawa samostanowienie realizuje się dwufazowo, według założeń tezy Habermasa o równej pierwotności autonomii obywatelskiej (Habermas, [1992] 2005, s. 106-110, 121-123; [1996] 2009, s. 83, 254-257).

Pierwsza faza związana jest $\mathrm{z}$ procesem prawotwórczym, realizowanym w dyskursywnej komunikacji zaangażowanych podmiotów prawnych. Indywidualny udział w tworzeniu prawa jest najważniejszym uprawnieniem obywatelskim. Motywacja samostanowienia pochodzi tu z wolności i praw podstawowych. Pozostają one niezmiennie zakorzenione w uniwersalnej moralności, w której również zakotwiczały potencjały samostanowienia mieszczan. Ażeby jednak dyskursywna komunikacja obywateli zdołała wytwarzać prawo, musi się stać częścią instytucjonalnego procesu demokratycznego. Do tego konieczny jest kod legalny, ustanowiony w stowarzyszeniach obywatelskich, powołanych do istnienia mocą zaangażowania indywidualnych wolności zrzeszania się. Pierwsza faza samostanowienia realizuje się zatem w obywatelskiej wolności: tworzenia stowarzyszeń obywatelskich i uczestnictwa w realizacji ich zadań. Są one niezbędne do wytworzenia kodu legalnego, który instytucjonalizuje komunikację nieformalną (Habermas, [1992] 2005, s. 581 n.)

Druga faza samostanowienia jest bezpośrednio związana z komunikacja aktorów społecznych. Habermas uznaje ją za najbardziej odpowiadającą arystotelesowskiej idei „starożytnych wolności politycznych” w ideowo niejednorodnym społeczeństwie postmetafizycznym. Normatywność komunikacji zakotwicza w republikańskiej wolności kolektywnego samostanowienia poprzez konstruktywne samourzeczywistnienie. Komunikacja dyskursywna wytwarza prawowitość uznawaną w warunkach pluralizmu ideowego, ażeby jednak mogło to nastąpić, wpierw musi uzyskać rangę i status instytucji. Przekonwertowanie komunikacji z nieformalnej wymiany opinii w instytucję dokonuje się również za pośrednictwem wspomnianego wcześniej kodu legalnego. $\mathrm{W}$ ten sposób komunikacja funkcjonuje jako zasada demokracji (Habermas, 
[1992] 2005, s. 584-587). Normatywność sfery publicznej Habermasa w demokratycznym państwie najpełniej oddaje teza równej pierwotności autonomii obywatelskiej, w której integralnie splatają się dwie tradycje wolnościowe: liberalna tradycja praw wolnościowych (Menschenrechte) i republikańska tradycja politycznego samostanowienia (Volksouveränität).

\section{WNIOSKI}

W koncepcji sfery publicznej Habermasa historyczność i normatywność tworzą nierozerwalną całość, zawierającą desygnaty empirycznych stanów rzeczy oraz aspiracji i powinności moralnych. Öffentlichkeit jest synonimem słusznych roszczeń jako oddolne wyzwanie rzucane autorytaryzmom kolonizującym świat zwykłych ludzi: państwu absolutystycznemu i systemom. Historyczność sfery publicznej Habermasa jest związana z rozwojem instytucjonalnych struktur życia europejskiego mieszczaństwa; jej normatywność czerpie $\mathrm{z}$ uniwersalnej moralności, tj. indywidualnych praw podstawowych i umiejętności konstruktywnego, kolektywnego samostanowienia. Obydwie dyspozycje modelowo integruje etos mieszczański, dlatego Habermas znajduje w nim repozytorium zdroworozsądkowości obywatelskiej, którą aplikuje jako remedium na inercję polityczną w późnym kapitalizmie. Sfera publiczna, dla której Habermas szuka zakotwiczenia w uniwersalnej moralności, zachowuje swój sens normatywny w systemowym świecie demokratycznego państwa, gdy jako platforma komunikacji obywatelskiej staje się kluczowym instrumentem w procesie kreowania prawa.

\section{BIBLIOGRAFIA}

Allen A. (2012), The Public Sphere: Ideology and/or Ideal?, Political Theory, 40(6), s. 822-829.

Baker K.M. ([1992] 1996), Defining the Public Sphere in Eighteen-Century France: Variations on a Theme by Habermas, [w:] C. Calhoun (red.), Habermas and the Public Sphere, Cambridge, MA: The MIT Press, s. 181-211.

Böckenförde E.W. (1976), Staat, Gesellschaf, Freiheit, Frankfurt a. M.: Suhrkamp Verlag.

Brunkhorst H. (2009), Rationalität und Rationalisierung, [w:] H. Brunkhorst, R. Kreide, C. Lafont (hg.), Habermas-Handbuch. Leben-Werk-Wirkung, Stuttgart: Wissenschafliche Buchgesellschaf, s. 367-368.

Busch W. ([1995] 2001), Kunsttheorie/Kunstkritik, [w:] W. Schneiders (hg.), Lexikon der Aufklärung. Deutschland und Europa, München: C.H. Beck, s. 230-233.

Calhoun C. (2007), Nations Matter. Culture, History, and the Cosmopolitan Dream, London: Routledge Tylor \& Francis Group. 
Dews P. (1993), Faktizität, Geltung, Öffentlichkeit, Deutsche Zeitschrift für Philosophie, 41(2), s. 359-364.

Edgar A. (2005), Philosophy of Habermas, [b.m.w.]: McGill-Queen's University Press.

Eisenstadt, S.N. (2000), Multiple Modernities, Daedalus, 129(1), s. 1-29.

Eisenstadt, S.N. (2006), Public Spheres and Civil Society in Selected Pre-Modern Societies: Some Comparative Observations, Comparative Sociology, 5(1), s. 1-31.

Fleming M. (1993), Women and the „Public Use of Reason”, Social Theory and Practice, 19(1), s. 27-50.

Fraser N. ([1992] 1996), Rethinking the Public Sphere: A Contribution to the Critique of Actually Existing Democracy, [w:] C. Calhoun (red.), Habermas and the Public Sphere, Cambridge, MA: The MIT Press, s. 109-142.

Fraser N. (2009), Theorie der Öffentlichkeit, tłum. N. Gramm, [w:] H. Brunkhorst, R. Kreide, C. Lafont (hg.), Habermas-Handbuch. Leben-Werk-Wirkung, Stuttgart: Wissenschaftliche Buchgesellschaft, s. $148-155$.

Giddens A. (2006), Sociology, Cambridge: Polity Press.

Głażewski M. (2016), Kategoria wolności w teorii systemów autopojetycznych Niklasa Luhmanna, Przegląd Pedagogiczny, nr 2, s. 9-32.

Habermas J. ([1963] 1968), Verwissenschaftlichte Politik und öffentliche Meinung, [w:] J. Habermas, Technik und Wissenschaf als "Ideologie”, Frankfurt a. M.: Suhrkamp Verlag, s. 120-145.

Habermas J. ([1965] 1968), Erkenntnis und Interesse, [w:] J. Habermas, Technik und Wissenschaft als "Ideologie", Frankfurt a. M.: Suhrkamp Verlag, s. 146-168.

Habermas J. (1969a), Gegen einen positivistisch halbierten Rationalismus, [w:] Th. Adorno, R. Dahrendorf, H. Pilot, H. Albert, J. Habermas, K.R. Popper (hg.), Der Positivismusstreit in der deutschen Soziologie, Neuwied a. R.: Luchterhand Verlag, s. 235-266.

Habermas J. ([1961] 1969b), Über den Begriff der Politischen Beteiligung, [w:] J. Habermas, Ch. Oehler, L. von Friedburg, F. Weltz (hg.), Student und Politik. Eine soziologische Untersuchung zum politischen Bewußtsein Frankfurter Studenten, Neuwied/R: Luchterhand Verlag, s. 11-55.

Habermas J. (1970), Soziologische Notizen zum Verhältnis von Arbeit und Freizeit, [w:] J. Habermas, Arbeit, Erkenntnis, Fortschritt, Amsterdam: Verlag de Munter, s. 56-74.

Habermas J. ([1968] 1973), Erkenntnis und Interesse. Mit einem neuen Nachwort, Frankfurt a. M.: Suhrkamp Verlag.

Habermas J. ([1957/1964] 1976), Öffentlichkeit. Ein Enzyklopädiaartikel (1964), [w:] E. Faenkel, K.D. Bracher (hg.), Staat und Politik. Das Fischer Lexikon, Frankfurt a. M.: Fischer Taschenbuch Verlag, s. 220-226.

Habermas J. (1976), Können komplexe Gesellschafen eine vernünfige Identität ausbilden?, [w:] J. Habermas, Zur Rekonstruktion des historischen Materialismus, Frankfurt a. M.: Suhrkamp Verlag, s. 92-126.

Habermas J. ([1972] 1984), Wahrheitstheorien, [w:] J. Habermas, Vorstudien und Ergänzungen zur Theorie des kommunikativen Handelns, Frankfurt a. M.: Suhrkamp Verlag, s. 127-183.

Habermas J. (1988), Nachmetaphysisches Denken I. Philosophische Aufsätze, Frankfurt a. M.: Suhrkamp Verlag.

Habermas J. ([1985] 2000), Filozoficzny dyskurs nowoczesności, tłum. M. Łukasiewicz, Kraków: Towarzystwo Autorów i Wydawców Prac Naukowych Universitas. 
Habermas J. (2001), Kommunikatives Handeln und detranszendentalisierte Vernunft, Jürgen Habermas, Stuttgart: Reclam.

Habermas J. (2003), Die Moderne - ein unvollendetes Projekt, [w:] J. Habermas, Zeitdiagnosen. Zwölf Essays1980-2001, Frankfurt a. M.: Suhrkamp Verlag, s. 7-26.

Habermas J. ([1992] 2005), Faktyczność i obowiazywanie. Teoria dyskursy wobec zagadnień prawa i demokratycznego państwa prawnego, tłum. A. Romaniuk, R. Marszałek, Warszawa: Wydawnictwo Naukowe Scholar.

Habermas J. (2005), Zwischen Naturalismus und Religion. Philosophische Aufsätze, Frankfurt a. M.: Suhrkamp Verlag.

Habermas J. (2005a), Öffentlicher Raum und politische Öffentlichkeit. Lebensgeschichtliche Wurzeln von zwei Gedankenmotiven, [w:] J. Habermas, Zwischen Naturalismus und Religion. Philosophische Aufsätze, Frankfurt a. M.: Suhrkamp Verlag, s. 15-26.

Habermas J. ([1962] 2007), Strukturalne przeobrażenia sfery publicznej, tłum. W. Lipnik, M. Łukaszewicz, Warszawa: Wydawnictwo Naukowe PWN.

Habermas J. [1996] 2009, Uwzględniając Innego. Studia do teorii politycznej, tłum. A. Romaniuk, Warszawa: Wydawnictwo Naukowe PWN.

Habermas J. (2012), Nachmetaphysisches Denken II. Aufsätze und Repliken, Berlin: Suhrkamp Verlag.

Habermas J. ([1973] 2015), Legitimationsprobleme im Spätkapitalismus, Frankfurt a. M.: Suhrkamp Verlag.

Habermas J. (2019), Auch eine Geschichte der Philosophie I. Vernünftige Freiheit. Spuren des Diskurses über Glauben und Wissen, Berlin: Suhrkamp Verlag.

Hansen M. ([1972] 1993), Foreword, [w:] O. Negt, A. Kluge, Public Sphere and Experience. Toward an Analysis of the Bourgeois and Proletarian Public Sphere, tłum. P. Labanyi, J.O. Daniel, A. Oksiloff, Minneapolis, MN: The University of Minnesota Press, s. ix-xli.

Häberle P. (1969), Öffentlichkeit und Verfassung: Bemerkungen zur 3. Aufl. von Jürgen Habermas, Strukturwandel der Öffentlichkeit (1968), Zeitschrift für Politik. Neue Folge, 16(2), s. 273-287.

Hohendahl P.U. ([1992] 1996), The Public Sphere: Models and Boundaries, [w:] C. Calhoun (red.), Habermas and the Public Sphere, Cambridge, MA: The MIT Press, s. 99-108.

Hohendahl P.U. (2000), Einleitung, [w:] P.U. Hohendahl, R.A. Berman, K. Kenkel, A. Strum (hg.), Öffentlichkeit - Geschichte eines kritischen Begriffs, Stuttgart: Verlag J.B. Metzler, s. 1-7.

Hohendahl P.U., Russian P. (1974), Jürgen Habermas: „The Public Sphere” (1964), New German Critique, No 3, s. 45-48.

Holub R.C. (1994), Habermas Among the Americans: Modernity, Ethics, and the Public Sphere, German Politics \& Society, No 33, s. 1-22.

Höffe O. (1993), Eine Konversion der kritischen Theorie? Zu Habermas' Rechts-Staatstheorie, Rechtshistorisches Journal, Nr 12, s. 70-88.

Hölscher L. (1979), Öffentlichkeit und Geheimnis. Eine begriffsgeschichtliche Untersuchung zur Entstehung der Öffentlichkeit in der frühen Neuzeit, Stuttgart: Klett-Cotta.

Hułas M. (2019), Decydować samemu. Sfera publiczna jako „locus” autonomii wedtug Jürgena Habermasa, Lublin: Wydawnictwo KUL.

Jacoby E.G. (1971), Die moderne Gesellschaf im sozialwissenschaflichen Denken von Ferdinand Tönnies Eine biographische Einführung, Stuttgart: Ferdinand Enke Verlag. 
Kaniowski A. M. (1990), Filozofa spoteczna Jürgena Habermasa. W poszukiwaniu jedności teorii i praktyki, Warszawa: Kolegium Ortyckie.

Kellner D. (2009), Habermas, the Public Sphere, and Democracy: A Critical Intervention, s. 1-17, http://www gseis ucla edu/faculty/kellner/kellner html [dostęp: 6.03.2021].

Kleinstüber, H.J. (2001), Habermas and the Public Sphere: From a German to a European Perspective, The Public, 8(1), s. 95-108.

Koselleck R. (1972), Einleitung, [w:] O. Brunner, W. Conze, R. Koselleck (hg.), Geschichtliche Grundbegriffe. Historisches Lexikon zur politischen Sprache in Deutschland I, Stuttgart: Klett-Cotta, s. xiii-xxvii.

Koselleck R. ([1959] 2015), Krytyka i kryzys. Studium patogenezy świata mieszczańskiego, tłum. J. Duraj, M. Moskalewicz, Warszawa: Biblioteka Res Publiki Nowej.

Kramer L.S. ([1992] 1996), Habermas, History, and Critical Theory, [w:] C. Calhoun (red.), Habermas and the Public Sphere, Cambridge, MA: The MIT Press, s. 236-258.

Krasnodębski Z. (2005), Postkomunistyczna etyka i duch kapitalizmu, [w:] System wartości i norm społecznych podstawa rozwoju Polski, Gdańsk: Instytut Badań nad Gospodarką Rynkową/Fundacja Konrada Adenauera, s. 19-26.

Landes J.B. (1988), Women and the Public Sphere in the Age of the French Revolution, Ithaca: Cornell University Press.

Llanque Marcus (2003), Räsonnement und Deliberation. Zu einem Grundproblem öffentlicher Kommunikation bei Habermas, [w:] L. Laberenz (hg.) Schöne neue Öffentlichkeit. Beiträge zu Jürgen Habermas »Strukturwandel der Öffentlichkeit«, Hamburg: VSA Verlag, s. 171-195.

Locke J. ([1689-1690] 1824), An Essay Concerning Human Understanding in four Books, [w:] J. Locke, The Works in Nine Volumes, London: J Rivington, http://lf-olls3amazonawscom/ titles/761/0128-01_Bkpdf [dostęp: 28.06.2018].

Loewenstein J., Stevens P. (2004), Introduction: Charting Habermas's „Literary” or „Precursor” Public Sphere, Criticism, nr 46(2), s. 201-215.

Luhmann N. (1970), Öffentliche Meinung, Politische Vierteljahresschrift, 11(1), s. 2-28.

Mandeville B. [1705] 1957), Bajka o pszczołach, tłum. A. Glinczanka, Kraków: Państwowe Wydawnictwo Naukowe.

McCarthy T. (2009), Geschichte und Evolution. Zur Rekonstruktion des historischen Materialismus, [w:] H. Brunkhorst, R. Kreide, C. Lafont (hg.), Habermas-Handbuch. Leben - Werk - Wirkung, Stuttgart: Wissenschafliche Buchgesellschaft, s. 199-205.

Nathans B. (1990), Habermas's „Public Sphere” in the Era of French Revolution, French Historical Studies, 16(3), s. 620-644.

Outhwaite W. (2009), Habermas: A Critical Introduction, Cambridge: Polity Press.

Peters B. (1993), Die Integration moderner Gesellschafen, Frankfurt a. M.: Suhrkamp Verlag.

Randall D. (2008), Ethos, Poetics, and the Literary Public Sphere, Modern Language Quarterly, 69(2), s. 221-243.

Saccamano N. (1991), The Consolations of Ambivalence: Habermas and the Public Sphere, MLN 106(3), German Issue, s. 685-698.

Schneider F. (1966), Pressefreiheit und politische Öffentlichkeit: Studien zur Geschichte Deutschlands bis 1848, Berlin: Hermann Luchterhand Verlag. 
Schröter M.W. (2007), Jürgen Habermas, [w:] J. Nida-Rümelin, E. Özmen (hg.) Philosophie der Gegenwart in Einzeldarstellungen, Stuttgart: Alfred Kröner Verlag, s. 240-256.

Schumpeter J.A. ([1942] 2009), Kapitalizm, socjalizm, demokracja, Warszawa: Wydawnictwo Naukowe PWN.

Smith A. ([1759] 1853), The Theory of Moral Sentiments or an Essey towards an Analysis of the Principles by which Men Naturally Judge Concerning the Conduct and Character, First of Teir Neigboughs, and Aferwards of Temselves. To which is added, a Dissertation on the Origin of Languages, London: H.G. Bohn.

Smith A. ([1775-1776] 2007), Badania nad natura i przyczynami bogactwa narodów, t. 1, thum. S. Wolff, O. Einfeld, Z. Sadowski, Warszawa: Wydawnictwo Naukowe PWN.

Taylor, Ch. (2007), A Secular Age, Cambridge, MA: The Belknap Press of Harvard University Press.

Tönnies F. (1926), Fortschritt und soziale Entwicklung. Geschichtsphilosophische Ansichten, Karlsruhe: Verlag G. Braun.

Warner M. (2002), Publics and Counterpublics, Public Culture, 14(1), s. 49-90.

Zaret, D. ([1992] 1996), Religion, Science, and Painting in the Public Spheres in SeventeenthCentury England, [w:] C. Calhoun (red.), Habermas and the Public Sphere, Cambridge, MA: The MIT Press, s. 212-235.

\section{HISTORYCZNOŚĆ I NORMATYWNOŚĆ SFERY PUBLICZNEJ HABERMASA}

\section{Streszczenie}

Celem niniejszych studiów jest eksploracja historyczności i normatywności w koncepcji sfery publicznej J. Habermasa. Historyczność odnosi się do empirycznych okoliczności zaistnienia sfery publicznej; normatywność czyni z niej organizacyjno-regulującą zasadę nowoczesnego ustroju politycznego. W teorii Habermasa historyczność splata się z normatywnością, a połączenie to zawiera desygnaty zarówno: (1) empirycznych stanów rzeczy, jak i (2) emancypacyjnych aspiracji i moralnych powinności. Odpowiednio do swej funkcji mobilizowania dążeń zwykłych ludzi usiłujących uchronić się przed kolonizującym działaniem mocy autorytarnych (państwa absolutystycznego i świata systemów), sfera publiczna (Öffentlichkeit) jest synonimem moralnie uprawomocnionych roszczeń. Jej historyczność jest związana z na wpół instytucjonalnymi strukturami życia europejskiego mieszczaństwa; normatywność jest zakotwiczona w moralności uniwersalnej: wolnościach indywidualnych (Menschenrechte) i kolektywnym samostanowieniu (Volkssouveränität). Ponieważ obydwie dyspozycje znajdują modelowe odzwierciedlenie w etosie mieszczańskim, Habermas znajduje w nim repozytorium uniwersalnej zdroworozsądkowości, którą usiłuje aktualizować i aplikować jako remedium na inercję polityczną późnego kapitalizmu. W jego koncepcji sfera publiczna umocowana w moralności uniwersalnej zachowuje swój oryginalny sens normatywny w późnokapitalistycznym świecie systemowym i w państwie demokratycznym. Jako arena komunikacji obywatelskiej sfera publiczna jest nieodzownym instrumentem w procesie demokratycznego prawotwórstwa.

Słowa kluczowe: Habermas; sfera publiczna; normatywność; historyczność; nowoczesność; legalizm. 


\title{
HISTORICITY AND NORMATIVITY \\ OF HABERMAS'S PUBLIC SPHERE
}

\begin{abstract}
Summary
This paper explores historicity and normativity of J. Habermas's conception of the public sphere. Historicity refers to empirical circumstances in which the public sphere came into being; normativity makes it an organizational and regulative principle of modern political order. In Habermas's theory historicity intertwines with normativity, and in this combination are to be found references to both: (1) empirical facts and (2) emancipative aspirations and moral obligations. Due to its function to mobilize the strivings of ordinary people who seek to escape the colonizing effects authoritarian powers (absolutist state and the world of systems) produce, the public sphere (Öffentlichkeit) is regarded as a synonym for morally justified claims. Its historicity is related to the semi-institutional structures of an early European bourgeoisie; its normativity is rooted in universal morality: individual freedoms (Menschenrechte) and popular sovereignty (Volkssouveränität). Since both dispositions are represented in a model fashion in the bourgeois ethos, Habermas finds in it a repository of that universal sound reason whose new forms he strives to reinstate as a remedy for political inertia in developed capitalism. His notion of the public sphere meticulously underpinned by universal morality retains its normative sense in the modern world of systems and in the democratic state. By organizing the arena for civic communication, the public sphere serves as an indispensable instrument in a democratic legislation crafting process.
\end{abstract}

Keywords: Habermas; the public sphere; normativity; historicity; modernity; legalism. 